\title{
Batik Wastewater Treatment Using Simultaneous Process of Electrocoagulation and Electro-Assisted Phytoremediation (EAPR)
}

\author{
Rudy Syah Putra ${ }^{1,2, *}$, Aprilia Dwi Annisa ${ }^{1}$, and Sigit Budiarjo ${ }^{1}$ \\ ${ }^{1}$ Department of Chemistry, Faculty of Mathematics and Natural Sciences, Universitas of Islam Indonesia, \\ Jl. Kaliurang km. 14, Yogyakarta 55584, Indonesia \\ ${ }^{2}$ Environmental Remediation Research Group, Faculty of Mathematics and Natural Sciences, Universitas Islam Indonesia, \\ Jl. Kaliurang km. 14, Yogyakarta 55584, Indonesia
}

* Corresponding author:

tel: $+62-274-895920$

email: rudy.syahputra@uii.ac.id

Received: August 26, 2019

Accepted: January 20, 2020

DOI: $10.22146 /$ ijc. 47898

\begin{abstract}
The aims of the study are to identify the effectiveness of wastewater treatment from the Batik industry using a simultaneous of electrocoagulation (EC) and electroassisted phytoremediation (EAPR). Rough horsetail (Equisetum hyemale) was used as an accumulator plant in the EAPR system. Electrocoagulation was conducted for $1 \mathrm{~h}$ at a constant voltage of $20 \mathrm{~V}$ in $10 \mathrm{~L}$ solution, while EAPR was processed for 7 day at a constant voltage of $5 \mathrm{~V}$ in $17 \mathrm{~L}$ solution. The chemical oxygen demand (COD) of water was determined by closed reflux of colorimetric methods and heavy metal concentration was determined by flame-atomic absorption spectrophotometer. The results showed that the COD decreased by 69.6\% after 1 h of electrocoagulation process and up to $80.9 \%$ after the EAPR process. The concentration of $\mathrm{Cr}$ and $\mathrm{Pb}$ decreased as much as $25 \%$ and $8.52 \%$, respectively in the similar process. The simultaneous process could extend the heavy metal removal up to $0.28 \mathrm{mg} / \mathrm{L}$ for $\mathrm{Cr}$ and $0.09 \mathrm{mg} / \mathrm{L}$ for $\mathrm{Pb}$ in liquid wastewater from the initial concentration. These results showed that the levels of COD and heavy metal concentration in Batik wastewater have reduced in accordance with the Ministry of Environment Decree No. 5/2014 Republic of Indonesia regarding various industries wastewater standard with the threshold limit of $150 \mathrm{mg} / \mathrm{L}$ for COD and $1.0 \mathrm{mg} / \mathrm{L}$ for $\mathrm{Cr}$ on textile industry and $0.1 \mathrm{mg} / \mathrm{L}$ for $\mathrm{Pb}$ on Class I for another wastewater standard. The estimated cost of operation was US\$ $1.509 \mathrm{~m}^{-3}$ indicating the viability of Batik industry wastewater treatment.
\end{abstract}

Keywords: electrocoagulation; EAPR; Equisetum hyemale; phytoremediation; batik wastewater

\section{- INTRODUCTION}

Batik industry (i.e. an ingenious traditional textile in Indonesia) has potentially contributed hazardous pollutants to the environment. Direct discharge or unproper treatment of wastewater produced from these industries can be detected easily by a physical form in the environment, such as smell, and turbid color of water [1]. The largest pollutant from the Batik industry is from the dyeing process. Dye substances are usually nonbiodegradable organic compounds, which are source of environmental pollution. Naturally, dyes compound in aquatic environments can be decomposed by photo- degradation. However, these processes occurred in a slow chemical reaction which impacted on the accumulation of dye compounds in the aquatic environment faster than the ability of photodegradation process [2].

Today, there are many methods to process the Batik or other textiles wastewater such as coagulation, adsorption using activated carbon, and electrocoagulation [2]. However, those techniques are less effective and relatively complex process, so that it is needed a new method that is more effective and environmentally friendly. When compared with 
activated carbon, the electrocoagulation has several advantages including environmental-friendly, non-toxic process, and less residue. Many studies showed that electrocoagulation was an efficient technique for discharging the pollutants at surface water in the lowlands [3], urban wastewater [4], restaurant's waste [5], chromium metal waste [6], and industrial wastewater [7]. Those studies have consistently shown that the electrocoagulation is one of the most promising techniques for wastewater treatment with the efficiencies between 70 and $95 \%$ in terms of COD and BOD respectively and less sludge products than other alternative procedures [8].

Presently, phytoremediation is an effective and affordable technological that use plant process to extract, remove, degrade, or render harmless hazardous materials including metals and metal pollutants present in the soils, sediments, and groundwater [9-10]. This technology is environmentally friendly and potentially cost-effective toward conventional water clean-up techniques. However, its application has limitations since the cleanup depth is strictly determined by the length of the plant roots. The transport of contaminants is minimal to the aboveground harvestable, and the movement of contaminants is induced exclusively by slow plant root suction. Therefore the efficiency of contaminant removal is depending on the extension of the plant roots in the soil and water surface [11].

Electro-assisted phytoremediation (EAPR) is an enhancement method to phytoremediation, requiring electrically assistance to overcome the weaknesses of phytoremediation itself [12]. The methods had been extensively reported on the improvement of soil [13-15] and aquatic phytoremediation [16-19] for the removal of heavy metals using various aquatic accumulator plants such as Lemna minor, Lactuta sativa, water hyacinth (Eichornia crassipes) and water lettuce (Pistia stratiotes).

The main objective of this study was to determine the optimal operation conditions and operating cost of effluent treatment from the Batik industry using a simultaneous electrocoagulation and EAPR system. Therefore, in this study, two major issues were addressed. First, the development and evaluation of a simultaneous process of electrocoagulation and EAPR was investigated. In addition, the assessment of rough horsetail (Equisetum hyemale) that is used in the electrical enhancement of aquatic phytoremediation treatment of the Batik wastewater was performed. Second, the survival strategy of growing plants in wastewater was assessed by (i) evaluation of the survival indicator to determine the COD level and heavy metal tolerance; (ii) determination of stressing indicator using total chlorophyll content and chlorophyll $\mathrm{a} / \mathrm{b}$ ratio. In addition, the feasibility of operating cost on the effluent treatment of Batik wastewater was calculated.

\section{- EXPERIMENTAL SECTION}

\section{Batik Wastewater Sampling}

Batik wastewater was collected before the rainy season from the Batik workshop in Mantrijeron, Yogyakarta, Indonesia, at the discharged point (GPS $7^{\circ} 49^{\prime} 06.7^{\prime \prime} \mathrm{S} 110^{\circ} 22^{\prime} 00.3^{\prime \prime} \mathrm{E}$ ). The collected wastewater was directly used without preserved. The characteristics of wastewater such as $\mathrm{COD}, \mathrm{pH}$, and heavy metals $(\mathrm{Pb}$ and Cr) were shown in Table 1. The high COD concentration in the Batik wastewater occurred due to the presence of chemical substances used in these industries such as sodium silicate, sodium salt and sodium alginate [2021]. In this study, the Batik wastewater has initial COD

Table 1. Profiles of Batik wastewater compared with the Ministry of Environment decree No. 5/2014 Republic of Indonesia regarding various industries wastewater standard

\begin{tabular}{cccccc}
\hline \multirow{2}{*}{ Characteristics } & \multirow{2}{*}{$\begin{array}{c}\text { Batik } \\
\text { Wastewater }\end{array}$} & $\begin{array}{c}\text { Textile } \\
\text { Industry }\end{array}$ & \multicolumn{2}{c}{ Other Quality } & \multirow{2}{*}{ Unit } \\
\cline { 3 - 5 } & & 150 & 100 & 300 & $\mathrm{mg} / \mathrm{L}$ \\
$\mathrm{COD}$ & 214.8 & $\mathrm{~N} / \mathrm{A}$ & 0.1 & 1.0 & $\mathrm{mg} / \mathrm{L}$ \\
$\mathrm{Pb}$ & 0.47 & 1.0 & 0.5 & 1.0 & $\mathrm{mg} / \mathrm{L}$ \\
$\mathrm{Cr}(\mathrm{VI})$ & 0.16 & $6-9$ & $6-9$ & $6-9$ & N/A \\
\hline $\mathrm{pH}$ & 8.60 & & & & \\
\hline
\end{tabular}


concentration of $214.8 \mathrm{mg} / \mathrm{L}$. Usually the Batik or textile industry effluent contains high COD concentration than BOD [20,22-23].

\section{Plant Collection}

Rough horsetail (Equisetum hyemale) was collected based on a similar phytomorphology characteristic, which has the same number of stem segments and root density. Before being used in the EAPR system, the plants were undergoing the acclimation process to adapt the laboratory environment. Acclimation was proceeded in two steps. Initially, the plant was acclimated in a fresh water for 3 days and then the solution was changed to a Hoagland solution for the next 3 days. Hoagland solution contains the essential elements required by the plant for growth. $1 \mathrm{~L}$ of Hoagland solution was prepared by mixing of $0.00676 \mathrm{~g} \mathrm{KH}_{2} \mathrm{PO}_{4}$, $0.252 \mathrm{~g} \mathrm{KNO}_{3}, 0.59 \mathrm{~g} \mathrm{Ca}\left(\mathrm{NO}_{3}\right)_{2} \cdot 4 \mathrm{H}_{2} \mathrm{O}$, and $0.20 \mathrm{~g}$ $\mathrm{MgCl}_{2} \cdot 6 \mathrm{H}_{2} \mathrm{O}$ according to elsewhere publication [12].

\section{Electrocoagulation Process}

The wastewater was flown into the electrocoagulation reactor with the dimension of 35 (L) $\mathrm{cm} \times 20(\mathrm{~W}) \mathrm{cm} \times$ $20(\mathrm{H}) \mathrm{cm}$ and filled with a volume of $10 \mathrm{~L}$. The process was carried out for $1 \mathrm{~h}$ at constant voltage of $20 \mathrm{~V}$ (DC power supply, $60 \mathrm{~V} / 10 \mathrm{~A}$, SANFIX, Taiwan). The electrode used in the experiment was aluminum as anode and stainless-steel sheets as cathode for each consisted of 3 sheets with a dimension of $30(\mathrm{~L}) \mathrm{cm} \times 20(\mathrm{~W}) \mathrm{cm}$ and $3 \mathrm{~mm}$ thickness. This process was intended to decrease the COD concentration in the wastewater. The solution was then continued to the EAPR reactor for the removal of the remaining heavy metal concentration. Fig. 1 shows the schematic diagram of the simultaneous processes. At first, wastewater from the equalization tank was treated by electrocoagulation process and then continued by EAPR treatment to decrease high COD and heavy metal concentration. The performance of electrocoagulation and EAPR process were evaluated by removal efficiency (\%) of COD and heavy metal concentration as shown in Eq. (1).

Removal efficiency $(\%)=\frac{C_{o}-C_{f}}{C_{o}} \times 100$

where, $C_{o}$ was the initial concentration before treatment, and $\mathrm{C}_{\mathrm{f}}$ was the final concentration after treatment.

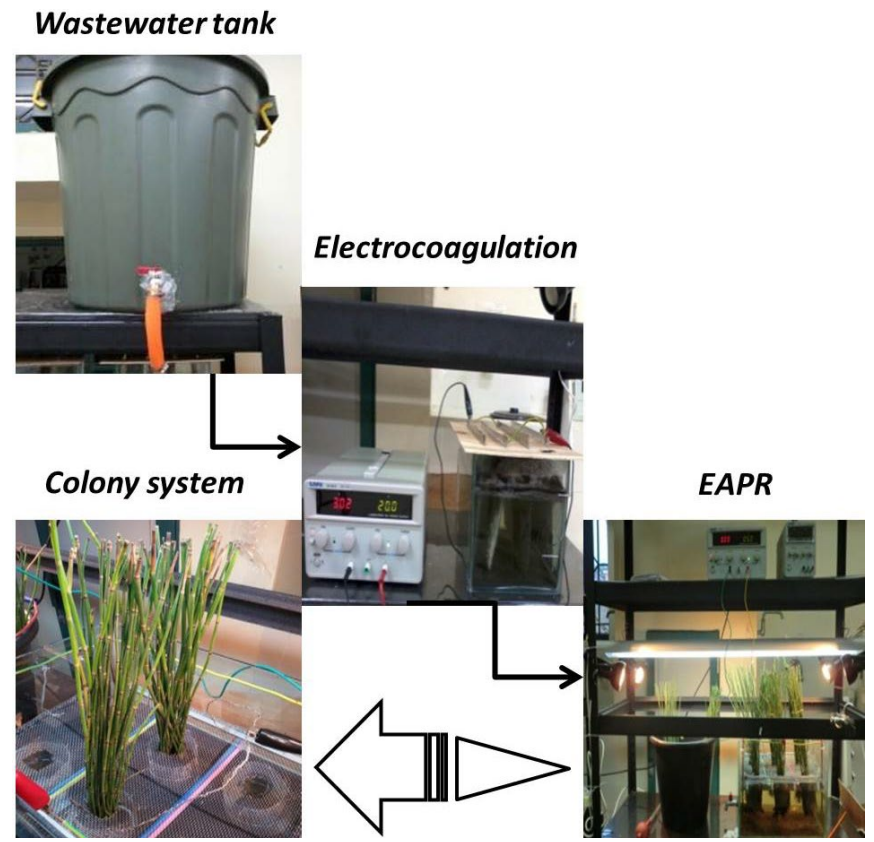

Fig 1. Simultaneous electrocoagulation process and EAPR treatment by which electrodes cathode of colony system. Rough horsetail (Equisetum hyemale) was used as an accumulator plant in the EAPR system

\section{EAPR Process}

After the electrocoagulation process, the wastewater then continued to flow into the EAPR reactor $(40(\mathrm{~L}) \mathrm{cm} \times 30(\mathrm{~W}) \mathrm{cm} \times 30(\mathrm{H}) \mathrm{cm})$ for $17 \mathrm{~L}$ volume, equipped with $\mathrm{Ti}$ as anode $(\varnothing 6 \mathrm{~mm} \times 25$ (L) $\mathrm{cm}$, Nilaco, Japan) and stainless steel U316 (net wire: 10 mesh, $30(\mathrm{~L}) \times 20(\mathrm{~W}) \mathrm{cm}$; and bar: $3 \mathrm{~mm}$ thick, $30(\mathrm{~L}) \times$ $1(\mathrm{~W}) \mathrm{cm}$ ) as cathode electrode. The process was carried out for 7 days at a constant voltage of $5 \mathrm{~V}$ (DC power supply, $30 \mathrm{~V} / 5 \mathrm{~A}$, SANFIX, Taiwan) using rough horsetail (Equisetum hyemale) as the accumulator plant. The light source was provided by fluorescent tubes (40 $\mathrm{W}$, Philips, Indonesia) and incandescent lamps (20 W, Osram Duluxstar PAR 38, China) which was controlled by an intra-matrix timer to provide $16 / 8 \mathrm{~h}$ light/dark cycle. In this process, a designed cathode-pot was used as electrode according to elsewhere publications [18-19].

\section{Water and Plant Tissues Analysis}

Six bundles of rough horsetail (Equisetum hyemale) were used in the EAPR system and for every two bundles was harvested consecutively at the $3^{\text {rd }}, 5^{\text {th }}$ 
and $7^{\text {th }}$ day of plantation. Those plants were weighed, washed thoroughly with running tap water and then separated into shoot and root. The shoot and root were cut into small pieces, dried for 5 days at $60{ }^{\circ} \mathrm{C}$ in an oven. Approximately $1.0 \mathrm{~g}$ of samples was digested in $10 \mathrm{~mL}$ concentrated $\mathrm{HNO}_{3}$ overnight and then evaporated for 15 mins on a hot plate until half of the initial volume. All solutions were adjusted to the final volume of $10 \mathrm{~mL}$ with deionized water. Heavy metal $(\mathrm{Pb}$ and $\mathrm{Cr}$ ) concentration was then measured by a flame atomic absorption spectrophotometer (Buck Scientific 202, USA). The concentrations of the element in this study were reported on a dry matter basis. The COD concentration in the water sample was determined by closed reflux of colorimetric methods according to SNI 6989.2:2009 with the reference method of $5220 \mathrm{D}$ [24].

\section{Chlorophyll Analysis}

The changes of the plants morphology were observed and monitored every day. The chlorophyll content of the plants was measured according to Moran and Porath [25]. A sample of $200 \mathrm{mg}$ plant shoots was cut into $0.5 \mathrm{~cm}$ segments and incubated in acetone for $24 \mathrm{~h}$ at $4{ }^{\circ} \mathrm{C}$ in a dark room. The absorbance of the supernatant was measured by a spectrophotometer (Hitachi 2000, Japan) at wavelengths $(\lambda)$ of 645 and $663 \mathrm{~nm}$. Chlorophyll concentrations $\left(\mathrm{mg} \cdot \mathrm{mL}^{-1}\right)$ were calculated by using the following Eq. (2) to Eq. (4).

$$
\begin{aligned}
& {[\mathrm{Chla}]=[12.7 \times \lambda 663]-[2.69 \times \lambda 645]} \\
& {[\mathrm{Chlb}]=[22.9 \times \lambda 645]-[4.68 \times \lambda 663]} \\
& {[\text { Total Chl }]=[8.02 \times \lambda 663]-[20.2 \times \lambda 645]}
\end{aligned}
$$

\section{Operating Cost}

Under the experimental studied, there are two main operating costs to be considered. The first process was the electrocoagulation and the second was the EAPR process. The operating cost for the electrocoagulation process was mainly from the electrodes wear and electric energy costs [26], while the EAPR process was only from the electric energy consumption [27]. In addition, there were some factors in both processes that should be considered such as labor, maintenance, sludge dewatering and disposal as well as fixed costs. The calculations of electrode wear [28], electric energy consumption, and operating cost were calculated by using the following Eq. (5) to Eq. (7).

$\mathrm{m}_{\mathrm{el}}=\frac{\text { i.t.M }}{\text { F.z }}$

$\mathrm{C}_{\mathrm{en}}=\frac{\text { U.i.t }}{\mathrm{V}}$

$\mathrm{C}_{\mathrm{op}}=\mathrm{a} \cdot \mathrm{C}_{\mathrm{en}}+\mathrm{b} \cdot \mathrm{C}_{\mathrm{el}}$

where $\mathrm{m}_{\mathrm{el}}=$ electrode wear, $\mathrm{C}_{\mathrm{en}}=$ energy consumption, $\mathrm{C}_{\mathrm{op}}=$ operating cost, $\mathrm{i}=$ Current $($ Ampere $), \mathrm{t}=$ Time $(\mathrm{sec}$ or h), $\mathrm{M}=$ molar mass (g), $\mathrm{F}=$ Faraday constant, $\mathrm{z}=$ Number of electrons, $\mathrm{U}=$ Electric tension (Voltage), $\mathrm{V}$ $=$ Volume $\left(\mathrm{m}^{3}\right), \mathrm{a}=$ Energy cost, $\mathrm{C}_{\mathrm{en}}=$ Energy consumption, $\mathrm{b}=$ cost of the plate, $\mathrm{C}_{\mathrm{el}}=$ Electrode consumption.

\section{- RESULTS AND DISCUSSION}

\section{Electrocoagulation Process}

Table 2 shows the concentrations of COD and heavy metal $(\mathrm{Pb}$ and $\mathrm{Cr})$ in the wastewater after $1 \mathrm{~h}$ of electrocoagulation process. The result showed that the electrocoagulation has decreased the COD concentration by $69.8 \%$, and the removal efficiencies of heavy metal was $8.5 \%$ and $25.0 \%$ for $\mathrm{Pb}$ and $\mathrm{Cr}$ respectively from the initial concentration. It is known that the removal of organic matter (i.e. COD) using electrocoagulation may involve electrochemical oxidation, adsorption by electrostatic attraction and physical entrapment [23]. In this step, the wastewater was treated only by electrochemical oxidation without further treatment, so that the resulted-effluent solution from this step still contained high organic matter. Therefore, the process was continued by the EAPR system to increase the removal of COD from wastewater. In this study, the aluminum electrode was used as an anode and stainless steel as a cathode. If the electric current passes through to the $\mathrm{Al}$ electrode, the $\mathrm{Al}^{3+}$ ions were generated electrochemically

Table 2. Profiles of $\mathrm{COD}$ and heavy metal $(\mathrm{Pb}$ and $\mathrm{Cr})$ concentration after $1 \mathrm{~h}$ of electrocoagulation process

\begin{tabular}{cccc}
\hline Condition & COD & \multicolumn{2}{c}{ Heavy metal $(\mathrm{mg} / \mathrm{L})$} \\
\cline { 3 - 4 } & $(\mathrm{mg} / \mathrm{L})$ & $\mathrm{Pb}$ & $\mathrm{Cr}$ \\
\hline Initial & 214.8 & 0.47 & 0.16 \\
After 1 h process & 65.3 & 0.43 & 0.12 \\
\hline
\end{tabular}


at the anode, and coagulant agents $\mathrm{Al}(\mathrm{OH})_{3}$ were formed as shown in the following Eq. (8) to Eq. (10). The formation of coagulant agent could decrease the heavy metal concentration together with organic substances in the wastewater. In this process, metal hydroxide has occurred because of hydroxyl ion production at the cathode during the electrocoagulation treatment. The solubility of a certain metal reaches a minimum at a specific alkaline condition, which has a characteristic value for each metal [23]. The $\mathrm{pH}$ of wastewater changed from 8.60 to 8.86 during the electrocoagulation treatment indicating more alkaline $\mathrm{pH}$ developed in the wastewater since hydroxyl $\left(\mathrm{OH}^{-}\right)$ions were continuously produced in the solution as shown in Eq. (9) to Eq. (10).

$$
\begin{aligned}
& \text { Anode }: \mathrm{Al}_{(\mathrm{s})} \rightarrow \mathrm{AL}^{3+}{ }_{(\mathrm{aq})}+3 \mathrm{e}^{-} \\
& \text {Cathode }: 3 \mathrm{H}_{2} \mathrm{O}_{(\mathrm{aq})}+3 \mathrm{e}^{-} \rightarrow 3 / 2 \mathrm{H}_{2(\mathrm{~g})}+3 \mathrm{OH}^{-}(\mathrm{aq}) \\
& \text { Hydrolysis: } \mathrm{Al}_{(\mathrm{aq})}^{3+}+3 \mathrm{OH}^{-} \rightarrow \mathrm{Al}(\mathrm{OH})_{3(\mathrm{aq})}
\end{aligned}
$$

\section{EAPR Process}

Fig. 2 shows the decreasing of COD concentration on the EAPR system for the 7 days process. The feed water for the EAPR treatment process (i.e. EA $1^{\text {st }}$ to $7^{\text {th }}$ ) resulted in the effluent from $1 \mathrm{~h}$ after electrocoagulation treatment (i.e. EC1) by which the COD concentration has been decreased by $69.8 \%$ from the initial concentration of wastewater. In the EAPR treatment process, the COD concentration continued to decrease until $80.4 \%$ (i.e. EA1 to EA7). In general, the simultaneous process of electrocoagulation (i.e. EC) and EAPR (i.e. EA) have been successfully performed to decrease the COD concentration in the wastewater from $214.8 \mathrm{mg} / \mathrm{L}$ to $42.2 \mathrm{mg} / \mathrm{L}$. The decreasing of $\mathrm{COD}$ in the phytoremediation process of Batik wastewater was a time consuming and the removal efficiency was depending on the plant used in the study. For example, degradation of COD using Egeria densa and Salvinia molesta achieved 95\% and $99 \%$ respectively for the 17 days process [29]. Therefore, the electro-assisted system aimed to extend the phytoremediation process on the removal of organic matter could simultaneously decrease the heavy metal concentration in the Batik wastewater [30]. A significant decreased of heavy metal concentration in the wastewater

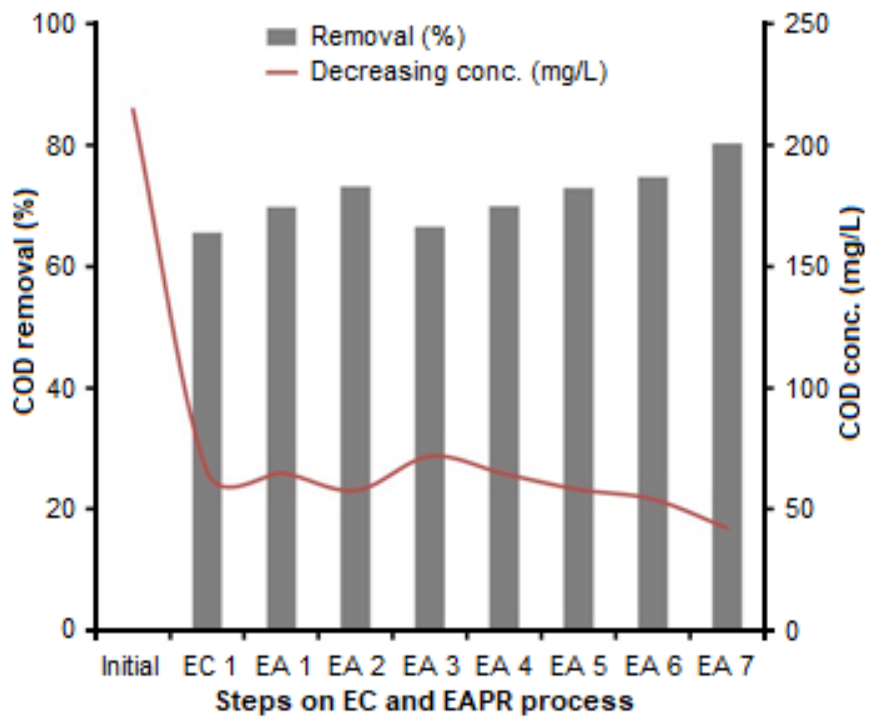

Fig 2. Profiles of decreasing COD concentration after electrocoagulation and continuing with the EAPR process on the treatment of Batik wastewater. EC1 indicates $1 \mathrm{~h}$ of electrocoagulation process and EA 1 to EA 7 indicates from $1^{\text {st }}$ to $7^{\text {th }}$ day of EAPR process

occurred from $3^{\text {rd }}$ to $7^{\text {th }}$ day of the EAPR process (Fig. are not shown). The removal of $\mathrm{Pb}$ and $\mathrm{Cr}$ concentration in the EAPR process decreased by $0.09 \mathrm{mg} / \mathrm{L}$ and $0.28 \mathrm{mg} / \mathrm{L}$, respectively. The decrease of lead and chromium concentration in the wastewater indicates the absorption of heavy metal by rough horsetail through an electroassisted process to the plants that occurred intensively. An acidified solution occurred around the anode when water hydrolyzed to form hydrogen ions $\left(\mathrm{H}^{+}\right)$. This acidic environment extended the lead ions $\left(\mathrm{Pb}^{2+}\right)$ migration toward the cathode and precipitated as metal-hydroxide around the cathode-pot electrode in the EAPR system as shown in Eq. (11) and Eq. (12). Moreover, those reactions have produced oxygen and hydrogen gas in the solution.

$$
\begin{aligned}
& \text { Anode }: \mathrm{H}_{2} \mathrm{O}_{(\mathrm{aq})} \rightarrow \mathrm{O}_{2(\mathrm{q})} \rightarrow \mathrm{O} 2(\mathrm{q})+2 \mathrm{H}^{+}{ }_{(\mathrm{aq})}+2 \mathrm{e}^{-} \\
& \text {Cathode }: 2 \mathrm{H}_{2} \mathrm{O}_{(\mathrm{aq})}+2 \mathrm{e}^{-} \rightarrow \mathrm{H}_{2(\mathrm{~g})}+\mathrm{OH}^{-}{ }_{(\mathrm{aq})}
\end{aligned}
$$

\section{Heavy Metal Concentration in the Plant}

Phytoremediation takes advantage of the unique and selective uptake capabilities of plant root systems, together with the translocation, bioaccumulation, and contaminant degradation abilities of the entire plant 
body [31]. In the EAPR system, the heavy metal absorption by plants was assisted by electrical migration of metal ions from the anode to cathode pot around the plant root which accelerated the plant to uptake ions from aquatic media [18-19]. Table 3 shows the accumulation profiles of $\mathrm{Pb}$ and $\mathrm{Cr}$ in shoot and root of rough horsetail plant. For hyper-accumulator plants, high translocation of the heavy metal from the root system would occur to the aerial part of plants, such as shoots and leaves [9]. In this study, despite the high level of lead and chromium concentration in the root, the ability of rough horsetail to translocate heavy metal from roots to shoots has low concentration for each treatment. Besides, heavy metal concentration in the plant tissues increased with the elevated EAPR process. The removal ability of heavy metal from the solution by the EAPR system was different (see Table 3). For example, a high uptake of lead was observed than that of chromium by rough horsetail (Equisetum hyemale). Regardless of chromium source in the environment, the potential of the plant species tested in phytoremediation was limited because high chromium concentration in the shoots was toxic to plants. Therefore, the most tolerant plant species accumulated the least amount of chromium. For example, metal-tolerant species like coastal Bermudagrass did not accumulate $\mathrm{Cr}$ more than $2 \mathrm{mg} / \mathrm{Kg}$ plant mass with $500 \mathrm{mg} / \mathrm{Kg}$ of soil [32-33]. In this study, chromium was still being measured after the treatment process even though the metal concentration was very low in the wastewater (see Table 1) because chromium has been recognized as a toxic, mutagenic and carcinogenic metal.

\section{Plant Stress Tolerance}

Plant appearance was observed, and chlorophyll content was measured to assess the tolerance of plants to heavy metal during the EAPR process. Total chlorophyll content and chlorophyll $\mathrm{a} / \mathrm{b}$ ratio are parameters for photosynthetic activity and often used as indicators of stress in plants. These parameters have been used for detecting and assessing the exposure of plants to environmental contaminants [34-35]. Fig. 3 shows the total chlorophyll and chlorophyll a/b ratio in the plant after the EAPR process.

In general, for plant treatments with the EAPR process at all harvesting time, the total chlorophyll contents significantly decreased except the plant harvested at $5^{\text {th }}$ day after cultivation. Similar results also showed that the chlorophyll $\mathrm{a} / \mathrm{b}$ ratio of the treated plant decreased compared to the control plant. Those results concluded that the plants exposed by the EAPR process were not under toxic chemical stressing which was confirmed by negative visual characteristics of phytotoxic symptoms (e.g. discoloration, pigmentation, yellowing, and withering). Regarding the pigment content, heavy metal-exposed plants showed a remarkable decrease of chlorophyll. Therefore, the rate of photosynthesis decreased significantly in response to the elevated heavy metal concentration. In other words, any changes in chlorophyll synthesis and activity used as the index of direct toxic effects of heavy metals [36].

\section{Calculation of the Operating Cost}

The calculation of electrode wear that was consumed during the electrocoagulation process was shown in Eq. (5) with the molar mass of aluminum is $26.982 \mathrm{~g} \mathrm{~mol}^{-1}$ and the oxidation number of the element is 3 .

$\mathrm{m}_{\mathrm{el}}=\frac{5 \times 3600 \times 26.982}{96485 \times 3}=1.6779 \mathrm{~g} \mathrm{Al}$

Table 3. Heavy metal concentration in the rough horsetail plant after EAPR process

\begin{tabular}{ccccc}
\hline \multirow{2}{*}{ Cultivation periods } & \multicolumn{2}{c}{ Shoot } & \multicolumn{2}{c}{ Root } \\
\cline { 2 - 5 } & $\mathrm{Pb}(\mathrm{mg} / \mathrm{Kg})$ & $\mathrm{Cr}(\mathrm{mg} / \mathrm{Kg})$ & $\mathrm{Pb}(\mathrm{mg} / \mathrm{Kg})$ & $\mathrm{Cr}(\mathrm{mg} / \mathrm{Kg})$ \\
\hline EA 3 & 53.3 & 12.3 & 274.2 & 111.5 \\
EA 5 & 68.9 & 21.1 & 287.0 & 116.2 \\
EA 7 & 83.3 & 23.5 & 312.9 & 109.7 \\
Control & 52.5 & 27.2 & 226.0 & 117.4 \\
\hline
\end{tabular}

EA 3, EA 5 and EA 7 indicate the cultivation period after $3^{\text {rd }}, 5^{\text {th }}$ and $7^{\text {th }}$ day of cultivation. At $7^{\text {th }}$ day was the last experimental time in the EAPR system before the plant was harvested. The control plant was phytoremediation without wastewater. All data were the average value from two replication. 

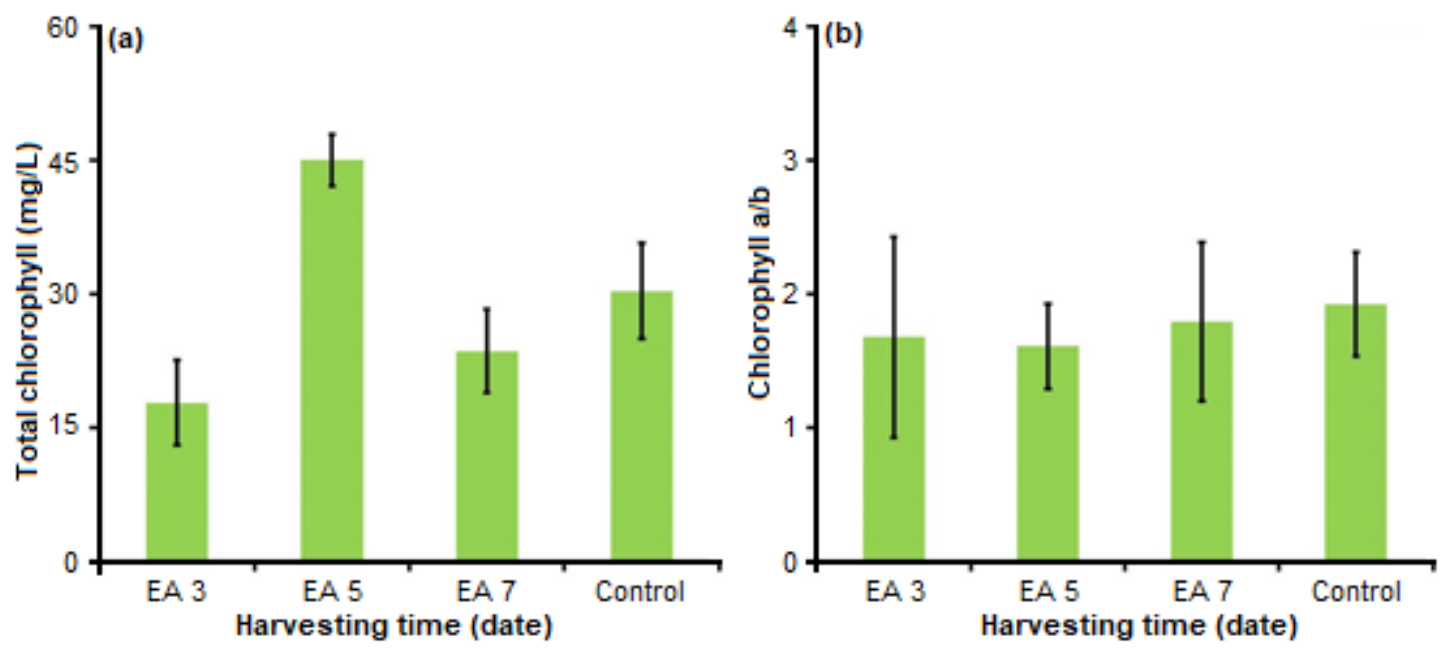

Fig 3. Total chlorophyll content (a) and chlorophyll $a / b$ ratio (b) in the plants after EAPR process for lead $(\mathrm{Pb})$ remediation $(\mathrm{n}=3)$. Chlorophyll in the control plant defined as the plant that grew in phytoremediation. EA 3, EA 5 and EA 7 indicate the cultivation period after the $3^{\text {rd }}, 5^{\text {th }}$ and $7^{\text {th }}$ day of cultivation

The energy consumption during the electrocoagulation (EC) and the EAPR process were calculated according to Eq. (6).

$\mathrm{C}_{\text {en }}(\mathrm{EC})=\frac{20 \times 5 \times 1}{0.01}=10000 \mathrm{Whm}^{-3}=10 \mathrm{kWhm}^{-3}$

$\mathrm{C}_{\text {en }}(\mathrm{EAPR})=\frac{5 \times 5 \times 1}{0.017}=1470.59 \mathrm{Whm}^{-3}=1.47 \mathrm{kWhm}^{-3}$

The operating cost of the batch reactor in the simultaneous of EC and EAPR system can be calculated using Eq. (7). The estimated value of $1.0 \mathrm{~kg}$ of aluminum plate is US\$2.30, but the mass estimated cost of a small plate (200 g) used in the experiment is US\$ 0.46. While, the value of industrial electrical energy in Indonesia (> $30000 \mathrm{kVA} /$ October 2019) is US $\$ 0.0643 \mathrm{kWh}$ (1 US $\$=$ IDR 15,500).

$$
\mathrm{C}_{\text {op }}=0.0643(10+1.47)+(0.46 \times 1.6779)=\text { US } \$ 1.509 \mathrm{~m}^{-3}
$$

The daily generation of effluent at the Batik industry was approximately $40 \mathrm{~m}^{3}$ per day [37]. Therefore, the monthly value was estimated by US\$ 1,811 .

\section{- CONCLUSION}

The results have demonstrated that the simultaneous process of electrocoagulation and EAPR process has been used to reduce significantly the concentration of COD and heavy metal $(\mathrm{Pb}$ and $\mathrm{Cr})$ in the Batik wastewater. In addition, rough horsetail (Equisetum hyemale) was able to grow well in the EAPR system while treating the Batik wastewater. According to the total chlorophyll and chlorophyll $\mathrm{a} / \mathrm{b}$ ratio, the plants were able to grow in Batik wastewater without showing a toxic chemical stressing. The results showed that the levels of COD and heavy metal (i.e. $\mathrm{Pb}$ and $\mathrm{Cr}$ ) concentration in Batik wastewater has reduced in accordance to the Ministry of Environment Decree No. 5/2014 Republic of Indonesia regarding of various industries wastewater standard with the threshold limit of $150 \mathrm{mg} / \mathrm{L}$ COD and $1.0 \mathrm{mg} / \mathrm{L}$ $\mathrm{Cr}$ for textile industry and $0.1 \mathrm{mg} / \mathrm{L} \mathrm{Pb}$ for another wastewater standard (Class I). The operating cost of mainly energy and electrode consumption was calculated as US\$ $1.509 / \mathrm{m}^{3}$ treated wastewater.

\section{- ACKNOWLEDGMENTS}

The author would like to thank the Ministry of Research, Technology and Higher Education (KEMENRISTEKDIKTI), the Republic of Indonesia for their financial support through Excellence Higher Education Institution Research (PTUPT) 2017-2018 (Research contract: 041/HB-LIT/IV/2017 and Ministry of Research, Technology and Higher Education contract: 663/M/KP/XII/2015). Furthermore, financial support from the Directorate of Talent Development and Student Welfare of Universitas Islam Indonesia to A.D.A and S.B. are also gratefully acknowledged. 


\section{- REFERENCES}

[1] Wardhana, W.A., 2001, Dampak Pencemaran Lingkungan, Andi Offset, 10-12.

[2] Pereira, L., and Alves, M., 2012, "DyesEnvironmental impact and remediation" in Environmental Protection Strategies for Sustainable Development, Eds. Malik, A., and Grohmann, E., Springer, Netherlands, 111-162.

[3] Jiang, J.Q., Graham. N., André, C., Kelsall, G.H., and Brandon, N., 2002, Laboratory study of electrocoagulation-flotation for water treatment, Water Res., 36 (16), 4064-4078.

[4] Smoczyński, L., Kalinowski, S., Ratnaweera, H., Kosobucka, M., Trifescu, M., and PieczulisSmoczyńska, K., 2017, Electrocoagulation of municipal wastewater - A pilot-scale test, Desalin. Water Treat., 72, 162-168.

[5] Adegoke, A.T., and Abayomi, E.T., 2020, A preliminary study on the treatment of restaurant wastewater using electrocoagulation technique, $J$. Degrade. Min. Land Manage., 7 (2), 2029-2033.

[6] El-Taweel, Y.A., Nassef, M.E., Elkheriany, I., and Sayed, D., 2015, Removal of $\mathrm{Cr}(\mathrm{VI})$ ions from wastewater by electrocoagulation using iron electrode, Egypt. J. Pet., 24 (2), 183-192.

[7] Butler, E., Hung, Y.T., Yeh, R.Y.L., and Al Ahmad, M.S., 2011, Electrocoagulation in wastewater treatment, Water, 3, 495-525.

[8] Barrera-Díaz, C., Linares-Hernández, I., RoaMorales, G., Bilyeu, B., and Balderas-Hernández, P., 2009, Removal of biorefractory compounds in industrial wastewater by chemical and electrochemical pretreatments, Ind. Eng. Chem. Res., 48 (3), 1253-1258.

[9] Raskin, I., 2000, Phytoremediation of Toxic Metals: Using Plants Clean Up the Environment, Eds. Raskin, I., and Ensley, B.D., Wiley, New York.

[10] Terry, N., and Banuelos, G.S., Phytoremediation of Contaminated Soil and Water, Lewis Publisher, Boca Raton.

[11] Hodko, D., Van Hyfte, J., Denvir, A., and Magnuson, J.W., 2000, Methods for enhancing phytoextraction of contaminants from porous media using electrokinetic phenomena, US Patent No. 6145244A.

[12] Putra, R.S., Ohkawa, Y., and Tanaka, S., 2013, Application of EAPR system on the removal of lead from sandy soil and uptake by Kentucky bluegrass (Poa pratensis L.), Sep. Purif. Technol., 102, 34-42.

[13] O Connor, C.S., Lepp, N.W., Edwards, R., and Sunderland, G., 2003, The combined use of electrokinetic remediation and phytoremediation to decontaminate metal-polluted soils: a laboratory-scale feasibility study, Environ. Monit. Assess., 84, 141-158.

[14] Aboughalma, H., Bi, R., and Schlaak, M., 2008, Electrokinetic enhancement on phytoremediation in $\mathrm{Zn}, \mathrm{Pb}, \mathrm{Cu}$, and $\mathrm{Cd}$ contaminated soil using potato plants, J. Environ. Sci. Health. Part A Environ. Sci. Health Part A Environ. Sci. Eng., 43 (8), 926-933.

[15] Zhou, D.M., Chen, H.F., Cang, L., and Wang, Y.J., 2007, Ryegrass uptake of soil $\mathrm{Cu} / \mathrm{Zn}$ by EDTA/EDDS together with a vertical direct-current electrical field, Chemosphere, 67 (8), 1671-1676.

[16] Bi, R., Schlaak, M., Siefert, E., Lord, R., and Connolly, H., 2011, Influence of electrical fields (AC and DC) on phytoremediation of metal polluted soils with rapeseed (Brassica napus) and tobacco (Nicotiana tabacum), Chemosphere, 83 (3), 318-326.

[17] Kubiak, J.J., Khankhane, P.J., Kleingeld, P.J., and Lima, A.T., 2012, An attempt to electrically enhance phytoremediation of arsenic contaminated water, Chemosphere, 87 (3), 259-264.

[18] Putra, R.S., Cahyana, F., and Novarita, D., 2015, Removal of lead and copper from contaminated water using EAPR system and uptake by water lettuce (Pistia stratiotes L.), Procedia Chem., 14, 381-386.

[19] Putra, R.S., Novarita, D., and Cahyana, F., 2016, Remediation of lead $(\mathrm{Pb})$ and copper $(\mathrm{Cu})$ using water hyacinth (Eichornia crassipes (Mart.) Solms) with electro-assisted phytoremediation (EAPR), AIP Conf. Proc., 1744, 020052. 
[20] Khalik, W.F., Ho, L.N., Ong, S.A., Wong, Y.S., Yusoff, N.A., and Ridwan, F., 2015, Decolorization and mineralization of Batik wastewater through the solar photocatalytic process, Sains Malays., 44 (4), 607-612.

[21] Şahinkaya, S., 2013, COD and color removal from synthetic textile wastewater by ultrasound assisted electro-Fenton oxidation process, J. Ind. Eng. Chem., 19 (2), 601-606.

[22] Holkar, C.R., Jadhav, A.J., Pinjari, D.V., Mahamuni, N.M., and Pandit, A.B., 2016, A critical review on textile wastewater treatments: Possible approaches, $J$. Environ. Manag., 182, 351-366.

[23] Kabdaşli, I., Arslan-Alaton, I., Ölmez-Hancı, T., and Tünay, O., 2012, Electrocoagulation applications for industrial wastewaters: a critical review, Environ. Technol. Rev., 1 (1), 2-45.

[24] Anonymous, 2009, Air dan air limbah - Bagian 2: Cara uji kebutuhan oksigen kimiawi (Chemical Oxygen Demand/COD) dengan refluks tertutup secara spektrofotometri, SNI 6989.2, Badan Standarisasi Nasional (BSN), Indonesia.

[25] Moran, R., and Porath, D., 1980, Chlorophyll determination in tissue using $\mathrm{N}, \mathrm{N}$ dimethylforamide, Plant Physiol., 65 (3), 478-479.

[26] Kobya, M., Demirbas, E., and Akyol, A., 2009, Electrochemical treatment and operating cost analysis of textile wastewater using sacrificial iron electrodes, Water Sci. Technol., 60 (9), 2261-2270.

[27] da Mota, I.O., de Castro, J.A., Casqueira, R.G., and de Oliveira Junior, A.G., 2015, Study of electroflotation method for treatment of wastewater from washing soil contaminated by heavy metals, J. Mater. Res. Technol., 4 (2), 109-113.

[28] Geraldino, H.C.L., Simionato, J.I, de Souza Freitas, T.K.F., Garcia J.C., de Carvalho Júnior, O., and Correr, C.J., 2015, Efficiency and operating cost of electrocoagulation system applied to the treatment of dairy industry wastewater, Acta Sci. Technol., 37(3), 401-408.

[29] Tangahu, B.V., and Putri, A.P., 2017, The degradation of BOD and COD of Batik industry wastewater using Egeria densa and Salvinia molesta, JSTL, 9 (2), 82-91.

[30] Tangahu, B.V., Ningsih, D.A., Kurniawan, S.B., and Imron, M.F., 2019, Study of BOD and COD removal in batik wastewater using Scirpus grossus and Iris pseudacorus with intermittent exposure system, J. Ecol. Eng., 20 (5), 130-134.

[31] Viehweger, K., 2014, How plants cope with heavy metals, Bot. Stud., 55 (1), 35.

[32] Shahandeh, H., and Hossner, L.R., 2000, Plant screening for chromium phytoremediation, Int. J. Phytorem., 2 (1), 31-51.

[33] Kale, R.A., Lokhande, V.H., and Ade, A.B., 2015, Investigation of chromium phytoremediation and tolerance capacity of a weed, Portulaca oleracea L. in a hydroponic system, Water Environ. J., 29 (2), 236-242.

[34] Aldoobie, N.F., and Beltagi, M.S., 2013, Physiological, biochemical and molecular responses of common bean (Phaseolus vulgaris L.) plant to heavy metals stress, Afr. J. Biotechnol., 12 (29), 4614-4622.

[35] Rastgoo, L., Alemzadeh, A., Tale, A.M., Tazangi, S.E., and Eslamzadeh T., 2014, Effects of copper, nickel and zinc on biochemical parameters and metal accumulation in gouan, Aeluropus littoralis, Plant Knowl. J., 3 (1), 31-38.

[36] Rastgoo, L., and Alemzadeh, A., 2011, Biochemical responses of gouan (Aeluropus littoralis) to heavy metals stress, AJCS, 5 (4), 375-383.

[37] Indrayani, L., 2018, Pengolahan limbah cair industri batik sebagai salah satu percontohan IPAL batik di Yogyakarta, Ecotrophic, 12 (2), 173-184. 